\title{
Cerebellar Form of Progressive Multifocal Leukoencephalopathy (PML)
}

\author{
JUSTIN PARR, DIKRAN S. HOROUPIAN, AND A. CHARLES WINKELMAN
}

SUMMARY: $A$ case of progressive multifocal leukoencephalopathy (PML) with selective involvement of cerebellum and brain stem is compared with nine other published cases. Recognition of $P M L$ presenting with ataxia before cerebral manifestations is stressed especially, since promising results with some antiviral drugs have been claimed.

RÉSUMÉ: Nous présentons un cas de leucoencéphalopathie multifocale progressive (LMP) avec atteinte sélective du cervelet et du tronc cérébral et nous comparons ce cas avec neuf autres publiés préalablement. Il est important de reconnaître tôt les cas de LMP avec ataxie avant l'apparition des manifestations cérébrales, surtout depuis que l'on prétend avoir obtenu des résultats prometteurs avec des médicaments antiviraux.

From the Division of Neuropathology, Hahnemann Míedical College, Philadelphia, PA and Neuropathology Division, Albert Einstein College of Medicine, Bronx, New York (DSH)

Reprint Request to: Dr. Justin Parr, University of Pennsylvania School of Medicine, Division of Neuropathology, 454 Johnson Pavilion/G2, Philadelphia, Pennsylvania, U.S.A., 19104

\section{INTRODUCTION}

PML is a subacute viral demyelinative disease. The virus is closely related to SV-40 and so far three strains SV40PML, JC and COL, have been cultured from brains with PML (Field et al., 1974). More than 100 cases of PML have been reported (Mathews et al., 1976). The clinical presentation is largely referrable to the cerebral hemispheres. Brain stem and cerebellar dysfunction, although described with some frequency in these cases, occurred late in the course of the disease and were often obscured by the cerebral manifestations. In nine cases, the disease process was largely confined to the cerebellum and brain stem, and cerebellar symptoms. occurred at onset (Davies et al., 1973; Woodhouse et al., 1967; Martin and Banker, 1969; Boudin et al., 1974; Vuia, 1976; Loken, 1974; and Gagne et al., 1977).

\section{Clinical history:}

The patient was a 54 year old Caucasian woman who developed progressive unsteady gait over a three to four week period, which resulted in her being unable to work as a secretary. Twenty-two years earlier, she had pulmonary sarcoidosis diagnosed on clinical grounds only. Pulmonary evaluation on admission revealed that she was free of symptoms and was classified as having stage III pulmonary sacrodosis with fibrosis. Initial neurological examination showed normal mental status. Her gait was ataxic and she had a tendency to hold her head to the left. She had difficulty keeping her eyes open and had slight left facial weakness. Incoordination was apparent in her left arm in addition to past pointing and decreased tone. In view of her history of sarcoidosis, she was given 20 $\mathrm{mg}$ of glucocorticoid qid and it was continued throughout her entire illness. After four weeks of hospitalization her symptoms progressed, but her mental status remained intact. She appeared chronically ill and weighed 94 lbs. Breath sounds were decreased bilaterally. Lymphadenopathy or organomegaly were not present. She had regular tachycardia $(124 / \mathrm{min})$, tachypnea $(24 / \mathrm{min})$, and a fever of $100^{\circ} \mathrm{F}$.

Her pupils were of equal size and reacted directly and consensually to light. Accommodation was present but slow. The optic fundi were normal. She had nystagmus on lateral gaze bilaterally, the fast component being in the direction of gaze. There was no ptosis, but abduction of the left eye was impaired. The left corneal reflex was absent and the right was decreased. Hypesthesia was present in the left face and was more pronounced over the forehead. Left facial weakness involved frontalis as well as lower facial muscles. Her speech was slurred, and swallowing was difficult as was protruding the tongue. The gag reflex was brisk bilaterally. Her head was tonically rotated to the left and the patient forcefully resisted any attempt to move it toward the midline. There were no meningeal signs. She was unable to walk because of the profound ataxia. Ataxia and decreased muscle tone were more marked in the left arm than in the other extremities. Deep tendon reflexes in the left arm were slightly increased, while in the lower extremities they were symmetrically depressed. Babinski reflex was present on the left and was equivocal on the right. During the twelfth week of illness, swallowing was impossible. 
Gram negative sepsis (E. coli) resulted in cardiac arrhythmias, severe hypotension, marked respiratory distress, and profound obtundation. With medical therapy, her mental status improved but she was no longer able to breathe spontaneously. Sleep apnea was a major problem in management. She developed bilateral facial paresis and loss of the right corneal reflex. Vertical eye movements were present but horizontal gaze was absent. The permanent tonic deviation of the head to the left disappeared. Cold water caloric stimulation produced nystagmus in the appropriate direction, the response on the left being more prominent than on the right. She had a flaccid quadriplegia although there was some withdrawal of the left arm and leg to painful stimuli. Over the final two days, she no longer responded to painful stimuli, caloric stimulation, or oculocephalic maneuvers. The pupils were approximately two to three $\mathrm{mm}$ in diameter and reacted to light. Roving eye movements with a horizontal component were present. During the last day of life she appeared awake and was able to look down, whereas on upward gaze there was deviation of the eyes to the right with accompanying nystagmus. In neutral position, there was prominent esophoria of the left eye. Several hours after this final neurological examination, she expired following bradycardia and asystole. This was three months after the onset of illness.

\section{Laboratory findings:}

CBC, SMA, urinalysis, sed. rate, blood chemistry, and electrolytes were within normal range. Thyroid function tests were normal. Serum proteins were up to $9.6 \mathrm{~g}$ with $5.1 \mathrm{~g}$ globulin during the fifth week of illness and decreased in the course of the disease to $6.0 \mathrm{~g}$ with $3.6 \mathrm{~g}$ albumin. Bilateral pleural thickening with interstitial fibrosis in the upper lobes, and bullae in the lower lobes were seen on chest x-rays. A Gallium lung scan was negative. Tuberculin skin test was non-reactive. Initial cerebrospinal fluid contained $29 \mathrm{mg} \%$ protein, 83 $\mathrm{mg} \%$ sugar, and no cells, whereas in the fifth week of illness it contained 9 $\mathrm{mg} \%$ protein, $92 \mathrm{mg} \%$ sugar, and chlorides of 92. The fluid pressures were normal.

Electromyography displayed prolonged nerve conduction time in the left facial nerve. EEG during the fifth week of illness showed 8 cycle per second activity and focal slowing of 3 to 4 cycle per second rhythms bilaterally. This was greater on the left. A left brachial arteriogram, a cervical and posterior fossa myelogram, computerized transaxial tomography, and pneumoencephalography were normal.

\section{Pathology:}

The autopsy was limited to examination of contents of the cranial cavity, and lungs (17 hours after death).

The brain weighed $1,220 \mathrm{~g}$. The leptomeninges and blood vessels were not altered. The cerebral and cerebellar hemispheres had normal configuration. The pons was swollen and had lost its surface corrugations. The origins of the third and fifth cranial nerves were displaced rostally and posteriorly, respectively, because of pontine swelling. On sagittal and horizontal sections, the brain stem displayed extensive chalky white softening (Figure 1). The lesion was poorly demarcated and was continuous throughout the basis pontis, medulla, both middle cerebellar peduncles, and the white matter of both cerebellar hemispheres (Figure 2 ). The cerebum was not remarkable.

The entire specimen was extensively sampled. The brain stem sections were oriented to the specific cranial nerve nuclei.

Paraffin sections were stained by hematoxylin and eosin with fuchsin (HE), luxol fast blue (LFB), phloxine fast breen (PFG), Heidenhain, cresyl violet $(\mathrm{CV})$, and gold toned silver protargol (Bodian). Frozen tissue sections were stained by oil red 0 (ORO). Formalin fixed sections from the softened pons were fixed in glutaraldehyde and stained with Dalton Osmium and embedded in Epon. Thin sections treated with lead citrate and uranyl acetate were examined with the Hitachi 11B electron microscope.

\section{Microscopic findings:}

The cerebellar white matter, middle cerebellar peduncles, and particularly the basis pontis contained large confluent foci of demyelination (Figure 2). The demyelination was continous with the lesion in the medulla (Figure 3). However, discrete foci, some of which were in the process of coalescence, were present at the periphery of the more diffusely involved areas. After careful search, only rare scattered microfoci of myelin

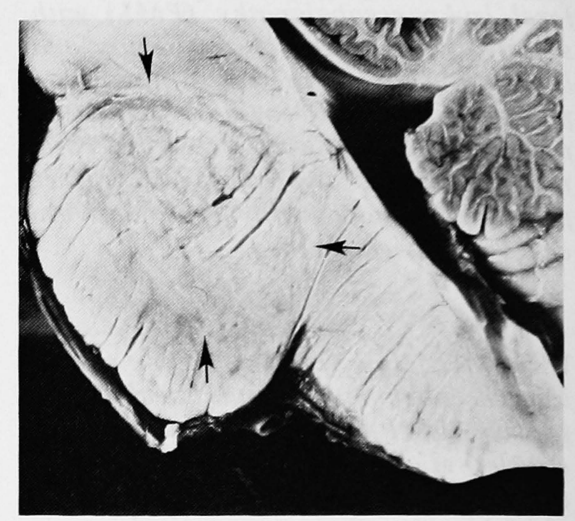

Figure I-Sagittal section displaying extent of lesion. Note granular area of softening in basis pontis (arrows).

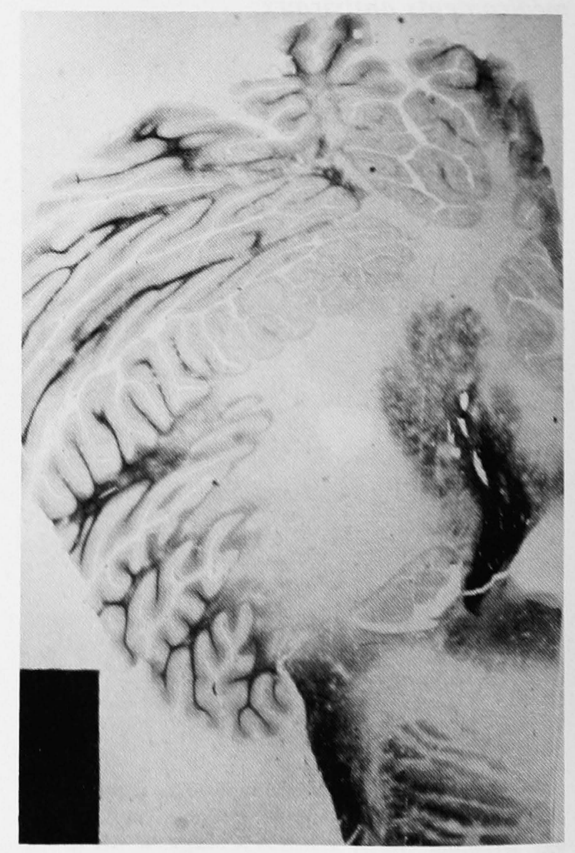

Figure 2-Horizontal plane displaying confluent loss of myelin involving pons, middle peduncle and cerebellum (Heindenhain). 
fragmentation were seen in the upper cervical spinal cord, mesencephalon, and frontal corona radiata white matter.

Desite the marked devastation of myelin, the neurons and axons were relatively preserved, although they were separated by collections of foamy macrophages and products of the disintegrated myelin. Perivenous lymphocytes were rarely seen. Giant astrocytes with bizarre nuclei were seen (Figure 4). Most of the astrocytes were of the plump reactive type. Astrocytosis was more advanced in the cerebellum whereas phagocytosis was pronounced in the pons.

In the periphery of the larger lesions and in the more discrete foci of demyelination, the nuclei of oligoden-

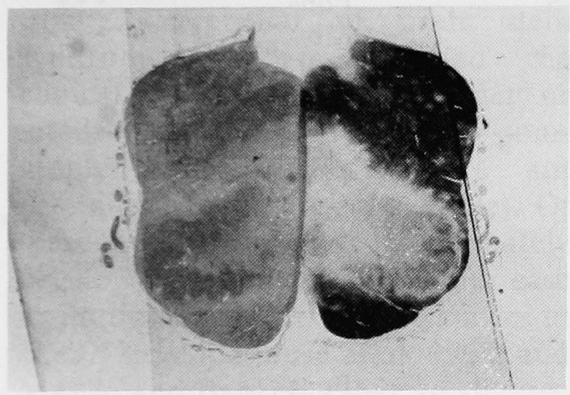

Figure 3-Composite of medulla. $\mathrm{R}$ is Heindenhain displaying confluent myelin loss. L is Bodian to illustrate relatively preserved axons. Note enlarged inferior olives.

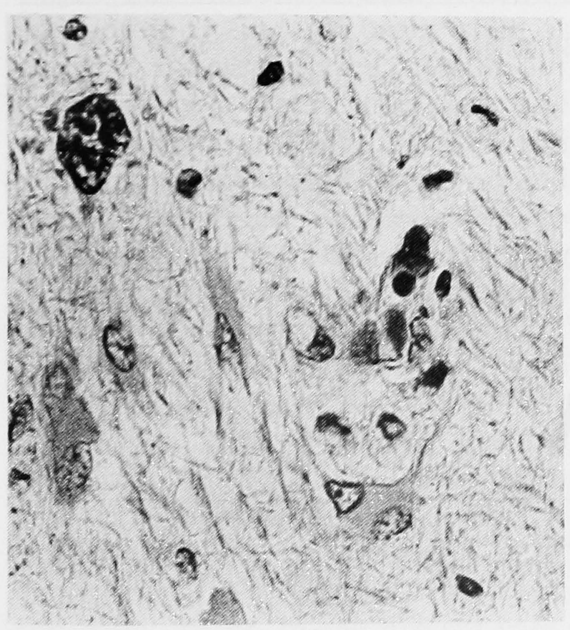

Figure 4-Coarse chromatin in bizarre astrocytic nucleus and reactive astrocytes (HE, 400x). droglia were enlarged to a variable extent and their chromatin patterns were altered. With $\mathrm{HE}$ and $\mathrm{CV}$ stains these cells had a flimsy irregular rim of cytoplasm. On the average, enlarged nuclei measured $15 \mu \mathrm{m}$ in diameter but a few measured up to $24 \mu \mathrm{m}$. They were distended with homogenous amphophilic material, and some contained dark punctate granules which were argyrophilic. Rarely, pleomorphic microglia were seen.

Within the rostral and midpons, the loss of myelin involved both the transverse and longitudinal fibers as well as the peripheral rim of myelin of the basis pontis. The demyelination did not extend into the tegmentum. The left fifth nerve root was filled with macrophages which displaced the axons. In the lower pons, the ventral half of the tegmentum contained multiple round foci of myelin loss some of which were confluent. The midline fiber tracts, central tegmental tracts, and trapezoid body were demyelinated. In the medulla, the medial lemnisci, central tegmental tracts, and olivary fiber tracts were severely demyelinated. The myelin was intact in the right pyramid, internal arcuate tracts, and extra-axial cranial nerve roots. Some of the intra-axial cranial nerve fibers were demyelinated as part of the confluent foci of myelin loss. Wallerian degeneration was not observed in the pyramids despite the devastation of the basis pontis. The olivary neurons were markedly enlarged and some of the changes were reminiscent of those seen in hypertrophy of the inferior olivary nuclei (HION) (Hououpian and Wisiniew-

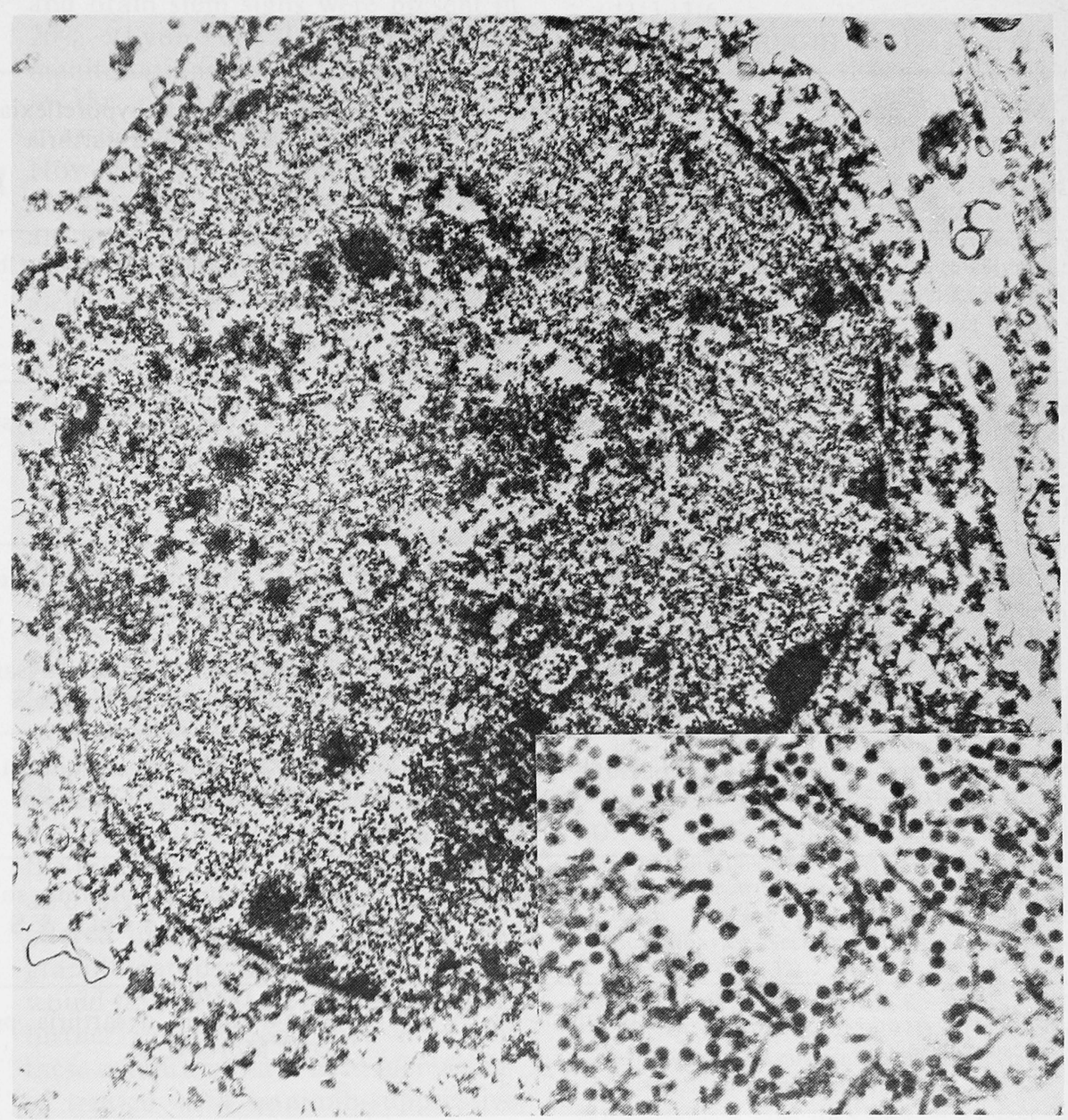

Figure 5 - E. M. of an oligodendroglial nucleus filled with virions (x 7,000). Insert: higher power of the virions (x 27,300). 
ski, 1971). However, filamentous proliferation (as seen in HION), was rarely seen.

\section{Electron microscopy:}

Ultrastructurally, the enlarged oligodendroglia nuclei were filled with virions that had the typical morphology of papovaviruses. Both the round and filamentous forms were present
(Figure 5). The former were about 39 $\mathrm{nm}$ in diameter and the latter $24 \mathrm{~nm}$ across. Occasionally, virions were also noted in the cytoplasm of the affected cells.

\section{Virology studies:}

Suspensions of fresh sections of inferior gyri of both temporal lobes were examined by electron micro- scopy, cell culture, and nucleic acid labeling. Ultrastructure particles 34-40 nm were seen in a low concentration suspension, but were not identifiable. Surprisingly, growth of the brain specimen cells was seen in co-cultivation with human fetal glia cells but they did not survive in subculture. Uridine or thymidine radiolabeled particles were not found.

PML WITH BRAIN STEM AND CBL FINDINGS

\begin{tabular}{|c|c|c|c|c|}
\hline Authors & Underlying disease & Signs and symptoms (S \& S) & Distribution & lesions \\
\hline $\begin{array}{l}\text { Richardson } \\
\text { NEJM - } 1961 \\
\text { (case 9) }\end{array}$ & Breast carcinoma & $\begin{array}{l}\text { F } 68 * \text {. Vertigo, brain stem and } \\
\text { Cbl S \& S. }\end{array}$ & $\begin{array}{l}\text { Cbl } \\
\text { Pons } \\
\text { Mdl } \\
\text { Cerebrum }\end{array}$ & $\begin{array}{l}-1 \\
+++ \\
+++ \\
+++ \\
++\end{array}$ \\
\hline $\begin{array}{l}\text { Woodhouse et al } \\
\text { Brain - } 1967 \\
\text { (case 2) }\end{array}$ & L. Sarcoma & $\begin{array}{l}\text { M } 34^{*} . \text { R. ataxia, hyporeflexia, } \\
\text { nystagmus, Mb and Mdl S \& S } \\
\text { Parkinsonism }\end{array}$ & $\begin{array}{l}\text { Cbl } \\
\text { Pons } \\
\text { Mb } \\
\text { Mdl } \\
\text { Frontal }\end{array}$ & $\begin{array}{l}+++ \\
++ \\
++ \\
++ \\
++\end{array}$ \\
\hline $\begin{array}{l}\text { Martin and Banker } \\
\text { Arch. Neurol. - } 1969\end{array}$ & R. C. Sarcoma & $\begin{array}{l}\text { M 71. Ataxia, hyporeflexia, } \\
\text { dementia, and dysarthria }\end{array}$ & $\begin{array}{l}\text { Cbl } \\
\text { Mb } \\
\text { Pons } \\
\text { Cerebrum }\end{array}$ & $\begin{array}{l}+++ \\
+ \\
+ \\
++\end{array}$ \\
\hline $\begin{array}{l}\text { Davies et al } \\
\text { Quart. J. Med. - } 1973 \\
\text { (case 1) }\end{array}$ & Hodgkin's & $\begin{array}{l}\text { F 44. Ataxia, dyarthria, Cbl } \\
\mathrm{S} \& \mathrm{~S} \text {, and dementia }\end{array}$ & $\begin{array}{l}\text { Cbl } \\
\text { Pons } \\
\text { Mdl } \\
\text { L. operculum }\end{array}$ & $\begin{array}{l}+++ \\
+++ \\
+++ \\
++\end{array}$ \\
\hline $\begin{array}{l}\text { Boudin et al } \\
\text { Revue Neurol. }-1974 \\
\text { (case 1) }\end{array}$ & C. Lymphocytic L. & $\begin{array}{l}\text { F 63. Diplopia, ataxia, nystagmus, } \\
\text { brain stem and Cbl S \& S }\end{array}$ & $\begin{array}{l}\text { Cbl } \\
\text { Pons } \\
\text { Mdl } \\
\text { Cerebrum }\end{array}$ & $\begin{array}{l}++ \\
++ \\
++ \\
++ \\
++\end{array}$ \\
\hline $\begin{array}{l}\text { Loken } \\
\text { Acta Pathol. } \\
\text { Microbiol. Scand.- } \\
1974\end{array}$ & $\begin{array}{l}\text { Lymphoma (case 1) } \\
\text { Lymphoma (case 2) }\end{array}$ & $\begin{array}{l}\text { M 63. Ataxia, dysarthria, dysphagia, } \\
\text { and Cbl S \& S } \\
\text { F 34. Ataxia, vertigo, dysarthria, } \\
\text { dysphagia, and Cbl S \& S }\end{array}$ & $\begin{array}{l}\text { Cbl } \\
\text { Brain stem } \\
\text { Cbl } \\
\text { Brain stem }\end{array}$ & $\begin{array}{l}-1 \\
+1 \\
++ \\
++ \\
++ \\
++\end{array}$ \\
\hline $\begin{array}{l}\text { Vuia } \\
\text { Eur. Neurol. - } 1976\end{array}$ & M. Myeloma & $\begin{array}{l}\text { M 72. Diplopia, dysarthria, nystagmus, } \\
\text { brain stem and } \mathrm{Cbl} \mathrm{S} \mathrm{\&} \mathrm{S}\end{array}$ & $\begin{array}{l}\text { Cbl } \\
\text { Pons } \\
\mathrm{Mb}\end{array}$ & $\begin{array}{l}++ \\
+ \\
++\end{array}$ \\
\hline $\begin{array}{l}\text { Gagne et al } \\
\text { Acta Neuropath. }-1977\end{array}$ & Immunodeficiency & $\begin{array}{l}\text { F 27. Nausea, vomiting, somnolence } \\
\text { dysarthria, and Cbl S \& S }\end{array}$ & $\begin{array}{l}\text { Cbl } \\
\text { Pons } \\
\text { Cerebrum }\end{array}$ & $\begin{array}{l}+++ \\
+++ \\
+\end{array}$ \\
\hline $\begin{array}{l}\text { X } 1926 \\
\text { Present case }\end{array}$ & ? Sarcoidosis & $\begin{array}{l}\text { F 54. Ataxia, dysarthria, pontine } \\
\text { and Mdl S \& S }\end{array}$ & $\begin{array}{l}\text { Cbl } \\
\text { Pons } \\
\text { Mdl } \\
\mathrm{Mb}\end{array}$ & $\begin{array}{l}+++ \\
+++ \\
+++ \\
+\end{array}$ \\
\hline
\end{tabular}

Cbl: cerebellum $\mathrm{Mbl}$ : medulla $\mathrm{Mb}$ : midbrain $\mathrm{F}$ : female $\mathrm{M}$ : male $\quad{ }^{*}$ age (in years)

+++ severe ++ moderate + mild 
It was concluded that the particles might have been viral, but the autopsy specimen did not contain the viable viruses, or else the temporal lobes were not infected.

\section{Lung and pituitary:}

The hilar and mediastinal lymph nodes were totally replaced by dense fibrous connective tissue. Pulmonary interstitial fibrosis, bullous emphysema, confluent acute bronchopneumonia, and pulmonary abscesses were present. Granulomas (sarcoidosis) were not present.

The beta cells of the adenohypophysis contained many cytoplasmic signet ring formations (Crook-Russel).

\section{DISCUSSION}

In reviewing the published cases of PML, a total of nine presented as an isolated cerebellar or brain stem syndrome which dominated the clinical course. Pyramidal tract or intellectual deficits which are commonly seen in PML were not prominent in these cases (Table). Of these nine, three patients ultimately developed dementia while in our case mentation remained intact (Davies et al, 1973; Woodhouse et al, 1967; and Martin and Banker, 1969). In all nine, the similarity of myelin loss in the cerebellar white matter and middle peduncles is remarkable. Perhaps this should be considered predictable as the principal anatomic site in the early diagnosis of the cerebellar form of PML. The amount of demyelination in continuity in the brain stem is variable in these reported cases. In our case and two others, the pons and medulla were markedly involved and the terminal illnesses were of two and one-half to three months duration (Davies et al, 1973; and Loken, 1974). Possibly, there is a temporal correlation between the length of illness and the distribution of brain stem involvement. In the cases of less than two and one-half months duration, the amount of brain stem involvement seemed less (Woodhouse et al, 1967; Martin and Banker, 1969; Richardson, 1961; Boudin et al, 1974; and Vuia, 1976). In the present case, the lesions in the medulla and the pons were more recent than those of the cerebellum even though they were in continuity by way of the middle peduncles. This assumption was based on the fact that gliosis was considerable in the cerebellum and minimal in brain stem. This suggested progression from an initial cerebellar affliction to brain stem. After diligent search and extensive sampling, we found only a few small microscopic foci in the cerebrum.

It follows from this brief review that a unique cerebellar syndrome in PML may occur in the initial presentation of the neurological illness. Any subdivision of PML into a cerebellar or ataxic variant based on clinicopathological correlation is arbitrary and should not be considered a nosological entity. In the majority of cases, there is much overlap between cerebral and cerebellar involvement late in the course of the disease. Cerebellar involvement occurred in $24 \%$ of all cases of PML and brain stem signs were present in $20 \%$ (Lyon et al., 1971). These manifestations usually appeared late in the course of illness and were overshadowed by cerebral signs. However, as in Creutzfeldt-Jakob disease (CJD), it should be accepted as an important variant in the initial presentation of the disease and should alert clinicians to this possibility (Gomori et al., 1973). The claims of beneficial results of cytarabine in inducing remissions in proven cases of PML places emphasis on this subject (Bauer et al., 1973; Conomy et al., 1974).

No major review has emphasized an ataxic or cerebellar variant of this disease (Richardson, 1970). Cerebellar diseases presenting in the middle-aged patient usually can be etiologically identified on the basis of history, examination and radiologic and laboratory findings. CJD and PML should be considered when the results of these studies do not confirm one of the more common diagnoses. Associated lympho-proliferative disorders, altered immunologic conditions, and granulomatous or collagen diseases would favor PML. This recognition is further emphasized since many of these conditions have been increasingly treated with immuno-suppressive agents which in turn predispose these patients to develop PML (Sponzilli et al., 1970).

\section{ACKNOWLEDGMENTS}

E. T. Lennette, Ph.D., of The Children's Hospital of Philadelphia, performed the virological studies. We are grateful for her assistance.

Dr. Jacob Zatuchni, of the Episcopal Hospital of Philadelphia, is the referring physician and we appreciate his cooperation.

\section{REFERENCES}

BAUER, W. R., TUREL, A. P., Jr., and JOHNSON, K. P. (1973). Progressive Multi-focal Leukoencephalopathy and Cytarabine. Journal of the American Medical Association, 226, 174-176.

BOUDIN, G., MIKOL, J., VERNANT, J. C., BYDLOWSKI, M., and BOUCHET, N (1974). Leucoencephalopathie Multifocale Progressive. Revue Neurologique, 130, 89102.

CONOMY, J. P., BEARD, N. S., MATSUMOTO, H., and ROESSMAN, H. (1974). Cytarabine Treatment of Progressive Multifocal Leukoencephalopathy. Journal of the American Medical Association, 229, 1313-1316.

DAVIES, J. A., HUGHES, J. T. and OPPENHEIMER, D. R. (1973). Richardson's Disease (Progressive Multifocal Leukoencephalopathy). Quarterly Journal of Medicine, 42, 481-501.

FIELD, A. M., GARDNER, S. D., and GOODBODY, R. A. (1974). Identity of a Newly Isolated Human Polyomavirus from a Patient with Progressive Multifocal Leukoencephalopathy. Journal of Clinical Pathology, 27, 341-347.

GAGNE, F., BOUCHARD, J. P., and BERNIER, J. P. (1977). Leucoencephalopathie Multifocale Progressive: Observation avec localisation lesionnelle electivement pontocerebelleuse et contexte d'insuffisance immunitaire congenitale. Acta Neuropathologica (Berl.) 38, 167-169.

GOMORI, A. J., PARTNOW, M. J., HOROUPIAN, D. S., and HIRANO, A. (1973). The Ataxic Form of CreutzfeldtJakob Disease. Archives of Neurology (Chic.), 29, 318-323.

HOROUPIAN, D. S., and WISNIEWSKI, H (1971). Neurofilamentous Hyperplasia in Inferior Olivary Hypertrophy. Journal of Neuropathology and Experimental Neurology, 30, 571-582.

LOKEN, A. C. (1974). Progressive Multifocal Leukoencephalopathy: A Neuropathological and electronmicroscopical study of two cases. Acta Pathologica et Microbiologica Scandinavica, Section A 1974, Supplementum 248, 127-132.

LYON, L. W., McCORMICK, W. F., and SCHOCHET, S. S. Jr. (1971). Progressive Multi-focal Leukoencephalopathy. Archives of Internal Medicine, 128, 420-426.

MARTIN, J. B., and BANKER, B. Q. (1969) Subacute Multifocal Leukoencephalopathy with Widespread Intranuclear Inclusions. Archives of Neurology (Chic.), 21, 590-602. 
MATHEWS, T., WISOTSKEY, H., and MOOSSY, J. (1976). Multiple Central Nervous System Infections in Progressive Multifocal Leukoencephalopathy. Neurology (Minneap.) 26, 9-14.

RICHARDSON, E. P. (1961). Progressive Multifocal Leukoencephalopathy. New England Journal of Medicine, 265, 815-823.

RICHARDSON, E. P. (1970). Progressive Multifocal Leukoencephalopathy. In: P. J.
Vinken and W. Bruyn (Eds.), Handbook of Clinical Neurology. North-Holland Publishing Co., Amsterdam. pp. 485-499.

SPONZILLI, E. E., SMITH, J. K., MALAMUD, N. and McCULLOCH, I. R. (1975). Progressive Multifocal Leukoencephalopathy: A Complication of Immunosuppressive Treatment. Neurology (Minneap.) 25, 664-668.
VUIA, O. (1976). Progressiye Multifocal Leucoencephalopathy and Rosenthal Fibres. European Neurology, 14, 198-208.

WOODHOUSE, M. A., DAYAN, A. D., BURSTON, J., CALDWELL, I., HUMEADAMS, J., MELCHER, O., and ULRICH, H. (1967). Progressive Multifocal Leukoencephalopathy: Electron Microscope Study of Four Cases. Brain 90, 863870. 